\author{
Volodymyr PATYKA ${ }^{1}$, Natalia BULETSA ${ }^{1}$, Lidiya PASICHNYK ${ }^{1}$ \\ Natalia ZHITKEVICH ${ }^{1}$, Antonina KALINICHENKO ${ }^{2,3^{*}}$, Tatiyana GNATIUK ${ }^{1}$ \\ and Lyudmyla BUTSENKO ${ }^{1}$
}

\title{
SPECIFICS OF PESTICIDES EFFECTS ON THE PHYTOPATHOGENIC BACTERIA
}

\author{
SPECYFIKA WPEYWU PESTYCYDÓW \\ NA BAKTERIE CHOROBOTWÓRCZE ROŚLIN
}

\begin{abstract}
The data concerning the effects of pesticides of different nature on the phytopathogenic bacteria was examined and summarized. Without extensive research on the mechanisms of interaction between pathogenic bacteria and pesticides in the literature review a similar message about microorganisms of soil and phyllosphere are included. The bacteria can be suppressed permanently by pesticides with a mechanism of action that universally affects biological processes in living systems. Long-term storage, ease of use and fast visible effect are the advantages of synthetic pesticides remedies. But chemical pollution, shifts in the balance of ecosystems, unpredictable effects of chemical pesticides on non-target objects are the drawbacks. Stimulation of resistance response in plants is unifying factor for all types of biopesticides. This is realized through localization of the pathogen during infection, blocking its further penetration, distribution and reproduction. The results of the study of effects of plant protection products on the phytopathogenic bacteria of main crops are described. Among all tested pesticides, thiocarbamate fungicides demonstrated significant inhibitory action on phytopathogens, but their effect may be neutralized by other constituents of multicomponent preparations. Triazole fungicides affect the causative agents of bacterioses of crops at a dose of more than $1 \%$ of the active substance in the nutrient medium. Insecticides and herbicides have little or no effect on phytopathogenic bacteria; however they can enhance morphological dissociations of some Pseudomonas strains, thereby increasing their ability to survive. The disadvantage of many biopesticides against phytopathogenic microorganisms is the difference between their efficacy in vitro and in vivo that is why the desired result is not achieved in field condition. In addition, biological pesticides often lose their activity causing the problem of constant search for new active antagonists. The fact that the sensitivity of phytopathogenic bacteria to pesticides is strain-dependent should be considered in practice, particularly, assessment of the antibacterial action of various preparations should not be limited to a single bacterial strain.
\end{abstract}

Keywords: pesticides, fungicides, efficiency, bacteriosis of crops, phytopathogenic bacteria, antibacterial activity

\footnotetext{
${ }^{1}$ Department of Phytopathogenic Bacteria, Institute of Microbiology and Virology NASU, Acad. Zabolotny 154, 03143 Kyiv, Ukraine, email: patykavolodymyr@gmail.com, bulecca@gmail.com, imv_phyto@ukr.net, Natalia-zit@yandex.ru,gnatuktatiana@gmail.com,plant_path@ukr.net

${ }^{2}$ Opole University, ul. R. Dmowskiego 7-9, 45-365 Opole, Poland, phone +48 787321587

${ }^{3}$ Poltava State Agrarian Academy, ul. Skovorody 1/3, 36003 Poltava, Ukraine

*Corresponding author: akalinichenko@uni.opole.pl
} 


\section{Introduction}

For a long period of rapid industrial development natural processes prevailing in biological communities was ignored by humanity. This attitude led to the violation of environmental performance. The negative changes in case of intensive agriculture deserve special attention. Was estimated that in the current conditions on the planet lives about 30,000 weed species, 10,000 species of harmful insects and other arthropods, 3000 species of nematodes, 120,000 species of fungi, pathogenic viruses 600 species and 100 species of phytopathogenic bacteria. In many countries a key role in protecting plants, thru effectiveness against target objects, have synthetic pesticides. The flip side of the coin it is widespread and often uncontrolled use the agrochemicals. All it leads to the accumulation of pesticides and their metabolites in ecosystem and, consequently, to disruption of food chains, to suppression of natural regulation of harmful agents and to pollution. With pesticide residues agricultural products loses primary commodity value and becomes potentially dangerous to human health [1]. In addition, the widespread use of pesticides is causes the population resistance in harmful agents. Therefore, the defence plants increase the dose and frequency of treatments, which also increases the negative effects [2].

Pesticides, depending on their chemical structure, fall in living cells in the form of aqueous solutions per concentration gradient (polar inorganic substances) or dissolved in the lipid layer of the membrane (lipophilic organic substances). Also are possible penetrations through the active transport with consumption energy of macroergic compounds. Mineral pesticides penetrate as ions or molecules, because the solubility of this class of drugs is directly proportional to the speed of permeability into the cell. However, the majority of pesticides belong to organic compounds that are mainly lipophilic. Having got in the living cell, pesticides change the physical and chemical properties of the cytoplasm, $\mathrm{pH}$, destroy membranes of organelles, violate the terms of normal functioning cellular proteins. Adaptive reactions to pesticides in organisms occur in the correction of various biochemical and physiological processes that ensure their continued existence of that anthropogenic load condition [3].

Usually, plant protection products classified under the action of harmful objects. But insecticides, fungicides, herbicides use in agriculture against target objects do not provide the removal of bacteria from ecosystem. Therefore, pesticides violate the ecological balance between bacterial and fungal microbiota, particularly that do not exhibit antibacterial action $[4,5]$. As result is growing problem of bacterial diseases. Moreover, in the world there is a tendency to spread and homogenization of the species composition of pathogens [6]. Bacterial plant diseases spread and acquired a global significance; their pathogens have become more aggressive and deleterious. For example, usually epiphytic species Pantoea agglomerans acquired ability to cause epiphytotic [7]. Important is wide host range of most the pathogens, especially concerning weeds, their ability to surviving on plant debris, which providing constant circulation of pathogens in agricultural phytocenosis. Pathogenic bacteria always accompany both cultural and wild plant species. Under favourable conditions they affect all organs of plants and seeds during the growing season. These worsen the quality and reduce the volume of harvest, leading to significant economic losses to agriculture. In addition, often in determining the etiology of the disease, found mixed bacterial and fungal infections of plants, which complicates diagnosis and identification of the pathogen. According to some authors, bacteriosis often preceded fungal disease. 
In Ukraine, by the efforts employees of Department of Phytopathogenic Bacteria investigated phytopathogenic and saprophytic bacterial microbiota surface and internal tissues of wheat, soybean and other species (Table 1). Revealed, that the quality composition of the dominant saprophytic epiphytic bacteria is different from the spectrum of endophytic bacteria. Studies have shown changing of quantitative and qualitative composition pathogenic, epiphytic and entophyte microflora depending on the phase growth and development of plant. Especially dangerous is widespread in the world and in Ukraine phytopathogenic bacteria Pseudomonas syringae, Pectobacterium carotovorum and Xanthomonas translucens, which affects crops and reduce grain yield by $40 \%$, and during epiphytotic - more than $70 \%$. Harmfulness bacterial diseases of cereals manifested in the formation of spots in different plant organs, violation of photosynthesis, the loss of individual organs or the whole plant; reducing the total number and length of ears, number and quality caryopsides in the ear.

Table 1

Characteristics of the main agents of grain and leguminous crops in Ukraine

\begin{tabular}{|c|c|c|c|}
\hline \multicolumn{2}{|c|}{ Species, pathovar } & The disease is caused by agent & Sensitive plants \\
\hline \multirow{7}{*}{$\begin{array}{c}\text { Pseudomonas syringae } \\
\text { pv.: }\end{array}$} & atrofaciens & Basal blight & \multirow{2}{*}{ Wheat } \\
\hline & coronafaciens & Halo blight & \\
\hline & \multirow{2}{*}{ syringae } & \multirow{2}{*}{ Leaf blotch } & Soybeans \\
\hline & & & Wheat \\
\hline & pisi & \multirow{2}{*}{ Bacterial blight } & Peas \\
\hline & tabaci & & Soybeans \\
\hline & lachrymans & \multirow{3}{*}{ Angular leaf spot } & Cucurbits \\
\hline \multirow{2}{*}{ P. savastanoi pv.: } & glycinea & & Soybeans \\
\hline & phaseolicola & & Haricot \\
\hline \multicolumn{2}{|c|}{ Pectobacterium carotovorum subsp. carotovorum } & Bacterial or stem rot & \multirow{2}{*}{ Wheat } \\
\hline \multicolumn{2}{|c|}{ Xanthomonas translucens } & Black chaff & \\
\hline \multicolumn{2}{|c|}{ X. vesicatoria } & Bacterial leaf spot & Tomatoes \\
\hline \multirow{2}{*}{ X. axonopodis pv.: } & glycinea & Bacterial pustule & Soybeans \\
\hline & phaseoli & Brown leaf spot & \multirow{4}{*}{ Soybeans, haricot } \\
\hline \multicolumn{2}{|c|}{ X. fuscans subsp. fuscans } & Bacterial blight & \\
\hline \multicolumn{2}{|c|}{$X$. heterocea } & Black leaf spot & \\
\hline \multicolumn{2}{|c|}{ Curtobacterium flaccumfaciens pv. flaccumfaciens } & Rusty-brown leaf spot & \\
\hline \multicolumn{2}{|c|}{ Agrobacterium tumefaciens } & Bacterial cancer & Different crops \\
\hline
\end{tabular}

The emergence and spread bacteriosis of legumes annually in different regions of Ukraine and generally in the world inflicts significant damage and happens phased. In the period from germination to flowering predominate diseases that cause phytopathogenic bacteria genus Pseudomonas [8], but mainly from the flowering phase and of the ovary bean, pathogens attached to them genus Xanthomonas, after which arises is a mixed infection [9].

In the fight against phyto pathogens arise some difficulties, because bacteria form a biofilm on the surface of plants which simultaneously performing structural and protective function, and in some cases - even the reserve of nutrients [5]. In such conditions, increase bacterial resistance to deficiency of nutrient substrate, temperature, exsiccation, ultraviolet radiation and to chemical pesticides. The problem is also exacerbated due to the small range of plant protection products from bacterial disease. With the used widely drugs, antibacterial effects have pesticides, which include metals $(\mathrm{Cu}, \mathrm{Hg}, \mathrm{Mn}, \mathrm{Zn}, \mathrm{Fe})$ or halogens 
$(\mathrm{Cl}, \mathrm{I})$. Quinolones and benzimidazole derivatives also showed the antimicrobial action. In many countries, the fight against bacteria in agriculture conducted by the copper substances and antibiotics. But appear are more resistant strains [10]. Also recommended for combating to bacterial diseases of plant, Fitolavin 300 (biological product based on bacillus) and Thiram (dithiocarbamate). But this is not enough, given the rapid adaptation of bacteria to bactericides substances. Therefore, in parallel with monitoring bacterial pathogens of plants, is searched the means of combat and control of their quantity on insignificant economically and safe environmentally level. We checked pesticides both chemical and biological origin. The environmental effects of synthetic pesticides estimated ambiguously. With proper use of pesticides, this compounds show a positive impact. On the other hand, the volume of pesticides so great that causes significant environmental shifts. Mutagenic, carcinogenic, allergenic effects of pesticides on biological objects were detected. Environmental pollution by the chemical toxicants, including mutagenic and genotoxic action violates not only the composition of microbial communities, but also leads to changes in the genetic apparatus. The result is a changing eco-physiological property of the microorganisms, environmental and epidemiological consequences of which are yet to be determined. Perhaps, adaptation to chemical elements promotes genetic rearrangements which determine microevolution bacteria. Such adaptations may be accompanied by increased pathogenicity of microorganisms and expanding the range of their hosts. Therefore, on the continuous reduction of pesticide residues in biogeocenosis focuses modern environmental strategy.

Having got in the soil, pesticides migrate down the profile with flow of rain and irrigation water. Speed and the deepness migration depend on the dose, volatility, adsorption of toxicants, as well as the aqueous and thermal regime of soil. Residual amounts of certain pesticides detected at a depth of 2 meters or deeper. Accordingly, pesticides significantly effects on soil microbiota, which alters the response from a high resistance to strong sensitivity. Under the influence of pesticides, most notably decrease the number of nitrifying microorganisms and soil fungi (Penicillium, Fusarium, Humicola, Mucor, Trichoderma). Bacteria (Pseudomonas, Corynebacterium, Flavobacterium) and actinomycetes are experiencing lesser stress, especially those associated with rhizosphere [11]. Suggest that the more negative effects of pesticides feel the autotrophic and diazotrophic bacteria - evolutionarily older organisms, the genetic basis of which was formed in the absence of physiologically active compounds in the Earth's primitive biosphere.

Interactions of pesticides with soil microorganisms are devoted much larger number of studies, compared the studying effect of pesticides on phytopathogenic bacteria [12]. However, some general aspects and biological mechanisms of action can be extrapolated on the phytopathogenic bacteria [3, 13], especially with regard to the origin of major pathogen's groups from soil. Often the researchers have noted the negative impact of agrochemicals on microorganisms [14]. However, the effect of pesticides on the microbiota is not always negative, and substantially depends on the type of used pesticide [15]. For example, entering to the soil organic residues as result a massive loss of weeds after herbicide application can increase the size of some groups of microorganisms [16]. 


\section{Herbicides}

The largest share of pesticides used both in Ukraine and abroad makes up herbicides [2]. The bacteria are sensitive to herbicides with mode of action affecting the universal biological processes in living systems. For example, herbicides from the sulfonylurea affect on the acetolactate synthase, which involved in the synthesis of valine, leucine and isoleucine in the plants and microorganisms. Toxic effects of drugs relative to fluorescent pseudomonades were neutralized by introduction of these amino acids into the medium. For example, sulfonylurea herbicides affect on the acetolactate synthase, which involved in the synthesis of valine, leucine and isoleucine in the plants and microorganisms. Toxic effects of drugs relative to fluorescent pseudomonades was neutralized by introduction these scarce amino acids into the medium. Authors explained difference of strains sensitivity with isomerism of this enzyme [17].

Amine salt of 2, 4-dyhlorfenol acetic acid suppressed in the experiment pure cultures of phytopathogenic bacteria Erwinia and Pseudomonas genera. This pesticide increased total carbon microbial biomass, growth and activity of phosphate mobilizing microorganisms, expressed in the increase of mobile phosphorus in the soil [18]. However, cross-reactions blocked in plants by herbicides, inherent for bacteria too, but they are capable to alternative ways of these processes. Many researchers have noted an increase in the number of microorganisms under the influence of herbicides. Moreover, according to the literature a large number of bacteria, especially from Pseudomonas genus have the ability to degradation of pesticides and the use of these xenobiotic as carbon sources [19]. The destruction of herbicides in the environment occurs via participation by the soil, epiphytic and endophytic bacteria, particularly by the principle of co-metabolism. For example, the effective utilization of atrazine bacteria from the Pseudomonas, Rhodococcus, Rhizobium, Ralstonia, Agrobacterium, Clavibacter, Nokardioides genera were described. Since xenobiotics are stress factor for microorganisms, the adaptation to it comprising forming genetically metabolic pathways of degradation. There is a gene expression atzABC atrazinechlorine hydrolase that can convert atrazine in 2-hydroxy atrazine. Speed of atrazine mineralization correlates with the presence and number of such genes. For this purpose, the most widely used Pseudomonas sp. Bacteria of this genus are able to withstand strong anthropogenic pressure and adapt to new chemical pollutants. Such adaptations can appear as like morphology changes and genotype of bacteria. Resistance and destructive ability of microorganisms relatively herbicides, gives reason to consider such bacteria as potential reductants of environment. Identified endophytes plants possessing destructors-genes of pesticides [20], conducted their selection and transfer in transgenic plants [21]. However, along with positive aspects, there is a hypothetical risk of bacterial transfer and horizontal distribution of these genes [22] and consequently, emergence of resistant populations of weed.

\section{Insecticides}

The unique enzymatic systems of plants are the targets of herbicides, which are absent in animals or humans, but in the case of insecticides is just the opposite. Similar reactions are inherent of warm-blooded animals, which cause most of the potential danger of insecticides for the human body. For example, enzymes organic phosphorus inhibitors, except esterases and lipases, inhibit the activity of trypsin, chymotrypsin, plasmin, 
thrombin. According to the literature triozephosphorous insecticides are highly toxic to bacterial and fungal soil organisms [23]. However, strains with the potential utilization of diazinon are isolated from soil. Diazinon-degradable Serratia marcescens strain is also able to utilize other organic phosphorous insecticides (chlorpyrifos, parathion and fenitorotion) [24], but less than representatives of Pseudomonas, Agrobacterium and Bacillus genera [25]. Plants are a source of microorganisms-destructors insecticides, especially rhyzosphere. Burkholderia genera strains with the ability to degradation of organic phosphorus fenitrotion insecticide, which are genetically related with representatives of soil and phylosphere microflora, was isolated and identified out of resistant insects [26]. In this case resulting in phytophage resistance acquired through symbiosis with OPC (organophosphorous compounds) bacteria-destructors. Pyrethroids lambda-cyhalothrin showed a clear stimulating effect regarding to the soil microflora, thus inhibiting mold fungi (fungistatic effect), especially at higher concentrations. Bacillus and Pseudomonas genera strains isolated from soil treated with the drug mentioned above are able to grow in an environment with pesticides and use it as a single carbon source. Thus one of the Pseudomonas sp. strains reduced concentration of lambda-cyhalothrin more than in 20 times in 60 days.

Most researches of insecticides action, as other pesticides are designed to determine the overall response of soil and phyllosphere microbial communities. So analysis of phospholipids fat acids (PLFA) showed that cypermethrin treatment plants led to a significant increase in the total bacterial biomass and decrease biomass mushrooms. Also it was observed the increasing of number Gram-negative bacteria of phyllosphere comparatively with gram-positive, which may be explained by usage of cypermethrin dominant group as a nutrient medium. In addition, new restriction fragments resulting PCR analysis showed that bacteria may play an important role in the degradation of insecticide. The disappearance of some restriction fragments points out the phyllosphere bacteria can serve as a potential indicator of microbial sensitivity to the effects of pyrethroid insecticides [27]. Researchers note similar results regarding neonicotinoids. Thus, imidacloprid reduces the total bacterial soil pool for 14-28 days. Number of Gram-negative bacteria increases in later experiments compared to Gram-positive bacteria. That is changes in quantitative and qualitative composition of soil microbiota occur. The authors argue that the existence of the phenomenon is caused by bacterial evolution towards the utilization of the given insecticide via the selective increase of the destructor population, which has been proven by the change in electrophoretic lanes of amplification products and decrease in the total amount of imidacloprid in specimens analyzed [28]. Such complex research establishes the fact of the Gram-negative bacteria percent increase, although they do not provide the information about the sensitivity and characteristic responses of phytopathogenic phyllo- and rhizosphere to insecticides.

\section{Fungicides}

Fungicidal pesticides group is the most studied and most effective in relation to bacteria. Firstly, by removing fungal-bacterial antagonism, fungicides also free an advantageous niche for bacteria $[4,5]$. Secondly, the antibacterial activity is demonstrated predominantly by metal-based pesticides, the usage of which in the contemporary rural economy significantly decreased as they were substituted by triazoles, benzimidazoles and thiocarbamates $[1,2,29]$. 
Fungicides can effect both on vital biochemical processes in pathogen cells and on the pathogenesis in plants (pseudo fungicides, elicitors). For example glycoprotein substance, arachidonic acid causes accumulation of phenolic compounds in potato tubers, causing resistance to late blight. Formations of phenolic and nitrogen compounds are stimulated in the wheat tissues by 4-thiocyanate aniline, but in cucumber and apple tissues - by phenyl urea derivatives. When processing pea plants monilikolin A polypeptide, ions of heavy metals (copper and mercury) cause the formation of pisatin phytoalexins and in plants beans - similar dynamic phaseolin antibiotic. Validamycin antibiotic inhibits myoinositol formation - pathogenesis factor of some mushrooms. Aluminium phosethyl in affected plants, unlike uninfected, stimulates phytoalexin-like substances and phenolic compounds synthesis. Elicitor general principle of action is to stimulate the immune response of plants, which is very effective in the fight against bacteriosis [30].

Fungicides composed of heavy metals $(\mathrm{Cu}, \mathrm{Hg}, \mathrm{Pb}, \mathrm{Sn}, \mathrm{Ag}$ and their salts) are related to specific inhibitors of enzymes and other vital cellular components. But this continuous action of preparations leads to the accumulation of metals and changes in biocenoses. For example copper and its compounds can inhibit soil and reservoirs microflora, thus disrupting the processes of mineralization of organic compounds, including pesticides. $\mathrm{Cu}$-containing preparations recommended for use against bacteriosis lead to selection of resistant strains of pathogens with typically plasmid-mediated [10].

Studies of previous years showed that some fungicides can induce mutations of pathogens and Salmonella test strains in the standard semiquantitative Ames test. For example Fundazol (benomil), Maxim (fludioxonil) thiophene (tiofanat-methyl) preparations, used for the protecting of cereals not inhibit the development of pathogens of these cultures, but have for their mutagenic effects. In addition, all three tested preparations exhibit mutagenic effect on test-strain $S$. typhimurium TA98. Mutagenic activity of pesticides is extremely dangerous environmental factor that can lead to the emergence of pathogens with increased aggressiveness and adaptability to agrocenosis conditions stimulates the growth of the highly aggressive pathogens population.

The advantages of synthetic crop protection are long-term storage. Most of these pesticides do not need sterile conditions during storage and usage. The other positive aspect of chemical pesticides is their quick action. The effect depends on their meeting with the target molecule in the cell, that is the speed and amplitude preparation action will depend on the concentration. Changes caused by xenobiotics residence in nature, their toxic effects, resources for their production, storage and utilization of preparations themselves or byproducts of their synthesis, remediation of contaminated soil and groundwater do not demonstrate benefit of chemical pesticides usage. Therefore, appropriate and environmentally safe is development and introduction of biological methods of plant protection.

\section{Biological preparations}

Biological plant protection based on the antagonism, competition and hyper parasitism phenomena. This method is to use the microorganisms and their metabolic products (inductors) to inhibit the development of pathogens and plant pests. Bio preparations exhibit suppressive effect against harmful object or to induce an immune response to it what provides plant resistance against pathogens and phytophagy. However, biological plant protection is not only in entering biological preparations in agrocenosis, but also in 
maintaining the natural enemies of pathogens that supports the natural regulation of pathogens.

Biological products mainly include pesticides based on viruses, bacteria and fungi. Principle of their action is in specialization of pathogen on a separate harmful form or on a narrow range of closely related species.

The most frequently used antagonists are fungi of Trichoderma, Trichothecium genera, radiant mushrooms (Actinomyces sp.), bacteria (Bacillus subtilis, P. aurefaciens) and their metabolic products. Thus, hyper parasite Tuberculina persicina inhibits the development of aecia, lyses aeciospore of rust fungi (Puccinia coronifera, P. graminis, Gymnosporangium sabinae and other) on their intermediate hosts. Pycnidiales Darluca filum mushroom parasites and significantly reduces the development of pathogens of wheat brown leaf rust, blister rust and cluster cup rust of gooseberry and black currant. Cicihnobolus cesati mushroom grows and develops on exogenous mycelium and conidia sporification of gooseberry, cucumber, apple and other crops mildew pathogens. Coniothyrium minitans mushroom parasites on sclerotia of white rot pathogen of many plant species (Sclerotinia sclerotiorum), charcoal rot (Sclerotium bataticola), and hyper parasite Sporidesmium sclerotiorum - on Sclerotium cepivorum sclerotia.

Among preparations Funhistop based on fungi the (Trichoderma viride fungi spores), BT Tryhodermin (Tr. lignorum fungi spores), Tryhovit (Tr. lignorum fungi spores), Kazumin (Streptomyces kasugaensis product of fungi fermentation), Mikosan B (Fomes fomentarius alkaline fungi extract + chitosan) are used. Also it is used metabolites of fungi such as antibiotics used for struggle against mycosis and bacteriosis: Trichothecin antibiotic is produced from culture fluid of Trichothecium roseum fungi, Phytobacteriomicin - from Streptomyces griseus or S. lavendulae.

Metabolites producers strains that are active against used pathogenic bacterial test cultures are detected in the study of Streptomyces's antagonistic activity isolated from Ukraine soil samples with different anthropogenic pollution. It is found that Clavibacter michiganensis 13a and Xanthomonas campestris $8003 \mathrm{~b}$ are the most sensitive, and Agrobacterium tumefaciens UKM B-1000 strain is least sensitive. But the used Pectobacterium and Pseudomonas strains are the most stable. However, metabolites of Streptomyces sp. L25 strain influenced on Pectobacterium carotovorum UKM B-1095. Also in comparison with previous years a significant decrease in the number of active Streptomyces's strains regarding to the Pseudomonas syringae UKM B-1027 ${ }^{\mathrm{T}}$ is revealed.

Bacterial preparations are used as antagonists against plant pathogens and are competitors to mushroom preparation. The most active kinds of bacteria are Pseudomonas and Bacillus.

It is well known antagonistic effect of representatives of Bacillus genus on various phyto pathogens. Preparations based on B. amyloliqefaciens, B. subtilis and B. thuringiensis for protection against pathogens and insect pests are created [31]. Bacteria of Bacillus genus is shown to inhibit the development of infection caused by Clavibacter michiganensis subsp. michiganensis in tomato. Preplanting treatment of seeds with suspensions Bacillus subtilis UKM B-7023 and Bacillus pumilus 3 helped increase plant resistance to bacterial disease of cancer, probably due to the bacteria synthesis of biologically active substances with antimicrobial properties. Between two strains of bacilli that differ in antagonistic properties against $C$. michiganensis subsp. michiganensis, only B. subtilis UKM B-7023 
strain, which is a part of the bacterial preparations for plant growing, showed a significant stimulating effect on the growth and development of tomato.

Identification of possible antagonistic action of its bases - Bacillus thuringiensis against representatives of most common and harmful pathogenic bacteria was conducted during the creation of biological insecticides Bitoksabacilin preparation. This strain showed an average level of antagonistic activity to Xanthomonas campestris pv. campestris 8003b and low level to Pseudomonas syringae UKM B-1027 ${ }^{\mathrm{T}}$, C. michiganensis subsp. michiganensis $10_{2}$, Agrobacterium tumefaciens UKM B-1000, C. michiganensis subsp. sepedonicum UKM Ac-1995. Bacteria Bacillus genus are able to produce exocellular amino acids including essential (threonine, alanine, tyrosine, histidine, valhin etc.) and vitamins in great amount.

Pseudomonas are promising group of bacteria for biological control because of colonization a wide range of single and dicot plants, and forming a stable association with the plant throughout the growing season. Rhizosphere saprophytic pseudomonas (P.fluorescens, $P$. putida, $P$. aureofaciens and other) are natural regulators phytopathogenic microorganisms number [32]. These nonspore-forming bacteria characterized by rapid growth, production of antibiotics, bactericins, siderophore, growth stimulants. Phenazine-1-carboxylic, phloroglucinol derivatives, pirolnitrin are found among antibiotics produced by pseudomonas. Siderophores of pseudomonas create stable complexes with trivalent iron, depriving many species of pathogenic fungi from required element of a food resulting in their development inhibition.

Extracellular proteases of bacterial antagonists play an important role in lysis of pathogens cell walls. Preparations, that hydrolyze cell walls, usually are mixture of different enzymes and they actually contain several proteases (hydrolases that cleave the peptide bond between amino acids in proteins).

The disadvantage of many bacterial and fungal preparations that are used against phytopathogenic microorganisms, is the difference between their efficacy in vitro and in vivo, therefore the desired results are not achieved in field conditions. Biological preparations often lose their activity the problem of constant search for new bacteria - active antagonists.

The use of biological products based on bacteriophages as a preventive and therapeutic agent of disease control has several advantages, such as high specificity of action; less probability of resistance development compared to antibiotics; the presence of lytic enzymes by which phages destroy exopolysaccharide matrix of bacterial biofilms that prevent the effective use of antibiotics or pesticides. The research data of bio preparation based on phages consortium indicate its activity against the bacteriosis pathogen of cucumber. Bio preparation contains physiologically active phages that can lysis cells of pathogenic bacteria of the Pseudomonas genus, namely $P$. syringae, $P$. fluorescens and P. putida bacteria.

Some researchers have noted a positive effect on the plants and reduce the manifestations of bacterial diseases due to the treatment of seeds or vegetative plant with amino acids. The experimental results showed that a specially selected set of amino acid positively affects sunflower plants by stimulating immunity to $P$. syringae phytopathogenic bacteria. Also there are reports about implementation in practice of protection of some plants by processing with extracts of others. Thus protein extract from the tops of potatoes is used as part of a wax citrus mixture [33]. 
The unifying factor for all types of bio pesticides is to stimulate plant response that may be triggered by a foreign body (bacteria, viruses, fungi) and its parts or metabolites [34]. Inductors of disease resistance are compounds that trigger signalling pathways of gene activation. They stimulate protection reactions and formation of plant resistance to fungal, bacterial and viral pathogens. This stability is realized through localization of pathogen in the course of infection, blocking its further penetration, distribution and reproduction in plants.

Natural inductors of basic stability include group of molecules of plant origin such as fragments of pectine, cutine, cellulose, xylose and other protective polymers that are released by the action of hydrolytic enzymes (cellulaze, cutinize and pectinaze) and plant organism perceives them as signals of pathogen presents. Plants receptors are able to recognize their own (endogenous) molecules associated with damage. It is created an effective preparations based on nonspecific elicitors of microorganisms - hyaluronic acid, chitin, chitosan and have practical application in plant protection.

\section{Materials and methods}

The collection strains of bacterial pathogens, which are used as test cultures to determine the toxic effects of pesticides chemical and biological origin were the object of research. Bacteria strains obtained from the collection of live cultures of phytopathogenic bacteria department of Zabolotny Institute of Microbiology and Virology of the NAS of Ukraine. Pesticides registered and approved for use in Ukraine were used in experiments (Table 2). The sensitivity of researched bacterial pathogens to preparations in laboratory conditions was checked by methods of pesticide introduction into nutrient medium - potato agar (PA) in a manufacturer recommended dose and by drop method. In the first case the action of preparations was evaluated by the presence or absence of bacterial cultures growth on Petri dish after 48 hours at $28^{\circ} \mathrm{C}$. In the second case, checking the presence of bacteria growth inhibition zones while introducing $0.1 \mathrm{~cm}^{3}$ (in the center of Petri dishes) of pesticides in recommended dose on the surface of the bacterial culture under the same conditions. Biopreparations were added to the Petri dish surface, inoculated bacterial suspension at a concentration of $10^{8} \mathrm{CFU}$ per dish.

Table 2

Researched pesticides substances

\begin{tabular}{|c|c|c|c|}
\hline $\begin{array}{l}\text { Pur- } \\
\text { pose }\end{array}$ & Chemistry class & Active substance of pesticides, concentration & $\begin{array}{l}\text { Used dose [g } \\
\text { or } \mathrm{cm}^{3} / 100 \\
\mathrm{~cm}^{3} \text { of PA] }\end{array}$ \\
\hline \multirow{8}{*}{$\frac{\tilde{d}}{0 \frac{0}{0}}$} & Chloroacetamid & Acetochlor, $90 \%$ & $0.66 \mathrm{~cm}^{3}$ \\
\hline & Triazine & Prometryn, $50 \%$ & $1.00 \mathrm{~cm}^{3}$ \\
\hline & $\begin{array}{c}\text { Phosphonic acid } \\
\text { derivative }\end{array}$ & Isopropylamine salt of glyphosate, $48 \%$ & $1.00 \mathrm{~g}$ \\
\hline & Pyrimidine derivatives & Clopyralid, $26.7 \%+$ Picloram, $6.7 \%$ & $0.10 \mathrm{~cm}^{3}$ \\
\hline & Triazinone & Metribuzin, $60 \%$ & $0.17 \mathrm{~g}$ \\
\hline & \multirow{2}{*}{$\begin{array}{c}\text { Sulfonyl urea } \\
\text { derivatives }\end{array}$} & Rimsulfuron, $25 \%$ & $0.10 \mathrm{~cm}^{3}$ \\
\hline & & Tribenuron-methyl, $75 \%$ & $0.02 \mathrm{~cm}^{3}$ \\
\hline & Combined herbicide & $\begin{array}{c}\text { Phenmedipham, } 10 \%+\text { Desmedipham, } 8 \% \text { (carbamic acid } \\
\text { derivatives) + Ethofumesate (benzofuran derivatives), } 10 \%+ \\
\text { Metamitron (triazinone), } 20 \%\end{array}$ & $0.33 \mathrm{~cm}^{3}$ \\
\hline
\end{tabular}




\begin{tabular}{|c|c|c|c|}
\hline $\begin{array}{l}\text { Pur- } \\
\text { pose }\end{array}$ & Chemistry class & Active substance of pesticides, concentration & $\begin{array}{c}\text { Used dose [g } \\
\text { or } \mathrm{cm}^{3} / 100 \\
\mathrm{~cm}^{3} \text { of PA] }\end{array}$ \\
\hline \multirow{3}{*}{ 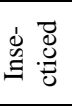 } & \multirow{2}{*}{ Pyrethroids } & Alpha-cypermethrin, $10 \%$ & $0.05 \mathrm{~cm}^{3}$ \\
\hline & & Lambda-cyhalothrin, $10.6 \%$ + Thiamethoxam, $14.1 \%$ & $0.06 \mathrm{~cm}^{3}$ \\
\hline & OPC + pyrethroids & Chlorpyrifos, $50 \%+$ Cypermethrin, $5 \%$ & $0.25 \mathrm{~cm}^{3}$ \\
\hline \multirow{17}{*}{ 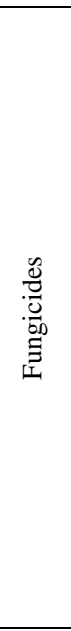 } & \multirow{6}{*}{ Triazole } & Difenoconazole, $25 \%$ & $0.13 \mathrm{~cm}^{3}$ \\
\hline & & Metconazole, $6 \%$ & $0.33 \mathrm{~cm}^{3}$ \\
\hline & & Penconazole, $10 \%$ & $0.08 \mathrm{~cm}^{3}$ \\
\hline & & Tebuconazole, $12 \%$ & $0.17 \mathrm{~cm}^{3}$ \\
\hline & & Tebuconazole, $16.7 \%+$ Triadimenol, $4.3 \%+$ Spiroxamine, $25 \%$ & $0.20 \mathrm{~cm}^{3}$ \\
\hline & & Epoxiconazole, $24 \%+$ Cyproconazole, $16 \%$ & $0.10 \mathrm{~cm}^{3}$ \\
\hline & \multirow{2}{*}{ Benzimidazole } & Benomyl, 50\% & $0.10 \mathrm{~g}$ \\
\hline & & Thiophanate-methyl, $70 \%$ (converted into carbendazim) & $0.40 \mathrm{~g}$ \\
\hline & Strobilurin & Kresoxim-methyl, $50 \%$ & $0.07 \mathrm{~g}$ \\
\hline & Phthalimide + elicitor & Folpet, $70 \%+$ Triadimenol, $1.5 \%$ & $0.67 \mathrm{~cm}^{3}$ \\
\hline & \multirow{5}{*}{ Thiocarbamates } & Thiram, $20 \%+$ Carboxin (carboxamide), $20 \%$ & $0.10 \mathrm{~cm}^{3}$ \\
\hline & & Mancozeb, $30.2 \%$ + Propamocarb hydrochloride, $24.8 \%$ & $0.50 \mathrm{~cm}^{3}$ \\
\hline & & Mancozeb, $80 \%$ & $0.10 \mathrm{~cm}^{3}$ \\
\hline & & Metiram, 70\% & $0.10 \mathrm{~cm}^{3}$ \\
\hline & & Mancozeb, $64 \%+$ Metalaxyl (phenylamide), $4 \%$ & $0.15 \mathrm{~cm}^{3}$ \\
\hline & $\begin{array}{c}\text { Derivatives of } \\
\text { phosphoric acid, elicitor }\end{array}$ & Aluminium phosethyl, $80 \%$ & $0.60 \mathrm{~g}$ \\
\hline & \begin{tabular}{|c|} 
Dithians \\
\end{tabular} & Dithianon, $70 \%$ & $0.17 \mathrm{~g}$ \\
\hline \multirow{4}{*}{ 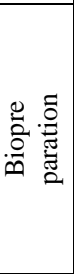 } & Biofungicide & Fitosporin-M - Bacillus subtilis, strain 26D, $10^{9} \mathrm{CFU}$ & $\begin{array}{c}10^{8} \text { CFU per } \\
\text { dish }\end{array}$ \\
\hline & Bioinsecticed & Lepidotsid - Bacillus thuringiensis var. kurstaki, $10^{9} \mathrm{CFU}$ & $\begin{array}{c}10^{8} \text { CFU per } \\
\text { dish }\end{array}$ \\
\hline & Elicitor & $\begin{array}{l}\text { Mikosan B- alkaline extract of the Fomes fomentarius fungus + } \\
\text { chitosan, } 3 \%\end{array}$ & $2.00 \mathrm{~cm}^{3}$ \\
\hline & Insectoacaricide & $\begin{array}{c}\text { Aktofit - complex of natural avermectin Streptomyces } \\
\text { avermitilis, } 0.2 \%\end{array}$ & $0.10 \mathrm{~cm}^{3}$ \\
\hline
\end{tabular}

Also bacteria cultured 24 hours in liquid nutrient medium with the recommended doses of pesticides and sowed aliquots of bacterial suspension in PA.

\section{Results}

During researches of pesticides influence on pure cultures we found that the effect of the drug on phytopathogenic bacteria depends on the presence and quantity of water molecules in the environment, namely: in liquid nutrient medium impact of agrochemical remedies is more significant than in composition of the nutrient agar medium. The possibility of pesticide passing through the cytoplasmic membrane also depends on the chemical composition, size and configuration of molecules, electric charge, solubility in lipids. Therefore, the absence of non-target pesticide antibacterial action can be also explained by the failure of active substances to penetrate cell membrane or disrupt its functioning in addition, most pathogenic bacteria form a biofilm, so their survival in the colony or microcolony is higher than in liquid cultivation.

Our results showed AN absence of significant influence of herbicides in concentrations recommended by the manufacturer on bacterial growth (Tables 3 and 4). But it should be 
admitted the strain sensitivity to specific preparations within a species that must be considered when testing new preparations.

Table 3

Sensitivity of grain crops bacteriosis pathogens to herbicides in the environment

\begin{tabular}{|c|c|c|c|c|c|c|c|}
\hline \multirow[b]{2}{*}{ Test strains } & \multicolumn{6}{|c|}{ Active basis of herbicides } & \multirow[b]{2}{*}{ ī } \\
\hline & 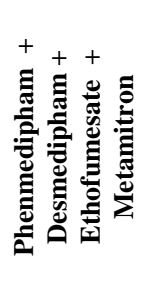 & 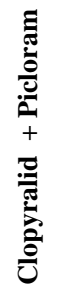 & 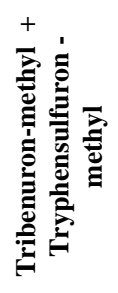 & 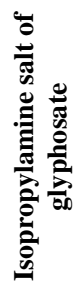 & 童 & 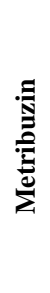 & \\
\hline \multicolumn{8}{|c|}{ P. syringae: } \\
\hline 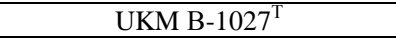 & \multirow[b]{2}{*}{+} & \multirow[b]{2}{*}{+} & \multirow[b]{2}{*}{+} & \multirow[b]{2}{*}{+} & \multirow[b]{2}{*}{+} & \multirow[b]{2}{*}{+} & \multirow[b]{2}{*}{+} \\
\hline $\begin{array}{c}\text { pv. atrofaciens } \\
\text { AF4, PDDCC 4394, 9747, 9780, } \\
\text { 9404, 9417, 912, P203, P204 }\end{array}$ & & & & & & & \\
\hline K20 & \pm & + & \pm & \pm & \pm & \pm & + \\
\hline $8462,9010,9400$ & + & + & + & \pm & + & + & + \\
\hline X. translucens 3164 & + & + & + & \pm & + & + & + \\
\hline
\end{tabular}

+- action absence, bacterial growth; \pm - weak sensitivity to the preparation, delayed bacteria growth

According to the data presented in the Table $4 P$. savastanoi shows sensitivity to the preparation with the rimsulfuron active substance, unlike tribenuron-methyl. Both herbicides are derivatives of sulfonylureas and block acetolactatesynthetase enzyme inhibiting valine, leucine, isoleucine synthesis. However affinity of the herbicide molecule with the active center of the enzyme depends on the unique isomerism of last one. It is also possible that selective action of preparations relatively $P$. savastanoi is associated with greater solubility, polarity and with number of open active groups of rimsulfuron molecules compared with tribenuron-methyl.

Table 4

Sensitivity of phytopathogenic bacteria of leguminous crops to sulphonylurea derivatives

\begin{tabular}{|r|c|c|}
\hline Test strains & Tribenuron-methyl & Rimsulfuron \\
\hline \multicolumn{2}{|c|}{ Xanthomonas axonopodis: } \\
\hline pv. glycines $8562,8835,8609,9075,8,17 \mathrm{v}, 2 \mathrm{~b}$ & + & + \\
\hline pv. phaseoli $1064,7992,7521$ & + & + \\
\hline \multicolumn{2}{|c|}{ Pseudomonas savastanoi: } \\
\hline pv. phaseolicola B-1032, B-1035, B-1036 & + & - \\
\hline pv. glycinea 8541, 8571, 9072, 9074 & + & + \\
\hline \multicolumn{2}{|c|}{ Pseudomonas syringae: } \\
\hline
\end{tabular}

+ - bacterial growth, action absence; - - absence of bacterial growth, sensitivity to the preparation 
The Agrobacterium and Clavibacter genera in pure culture are sensitive to chlorinesulfuron herbicide. In our research dangerous phytopathogenic A. tumefaciens UKM B-1000 strain demonstrated high sensitivity to prometrin as P. syringae UKM B-1027 $7^{\mathrm{T}}$. The presence of the same substance and acetochlor suppressed the growth of $P$. fluorescens in experiment (Table 5).

Table 5

Influence of herbicides on the leguminous crops pathogenic bacteria growth

\begin{tabular}{|c|c|c|}
\hline \multirow{2}{*}{ Test strains } & No growth zone diameter [mm] \\
\cline { 2 - 3 } & Prometryn & Acetochlor \\
\hline \multicolumn{2}{|c|}{ Pseudomonas: } \\
\hline syringae UKM B-1027 ${ }^{\mathrm{T}}$ & 38 & 0 \\
\hline fluorescens 8573 & 20 & 40 \\
\hline savastanoi pv. glycinea 9176 & 0 & 0 \\
\hline \multicolumn{2}{|c|}{ Xanthomonas: } \\
\hline campestris pv. campestris UKM B-1049 & 0 & 0 \\
\hline axonopodis pv.glycines 9075 & 0 & 0 \\
\hline Pectobacterium carotovorum UKM B-1095 ${ }^{\mathrm{T}}$ & 0 & 0 \\
\hline Clavibacter michiganensis $10_{2}$ & 50 & 0 \\
\hline Agrobacterium tumefaciens UKM B-1000 & \multirow{2}{*}{} \\
\hline
\end{tabular}

Our data shows that herbicide combined with active Tribenuron-methyl + Tryphensulfuron - methyl substances, despite the low concentration of active substance in the recommended dose, increases resistance of P. syringae UKM B-1027 ${ }^{\mathrm{T}}$ (NCPPB 281) and P. syringae pv. atrofaciens UKM B-1011 (PDDCC 4394) strain to streptomycin antibiotics (data not shown). This result can be regarded as mutagenic effect. A similar effect was observed in the study of hexachlorohexane impact on soil bacteria. However streptomycin-resistant mutants were more sensitive to organochlorine insecticide compared with the original strain.

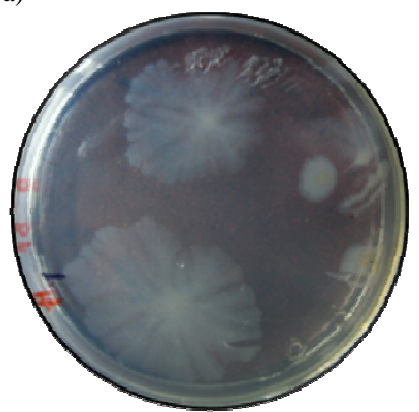

b)

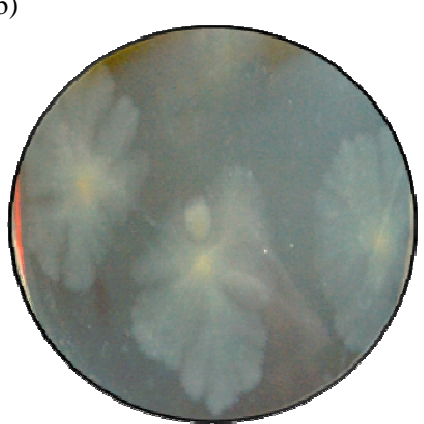

c)

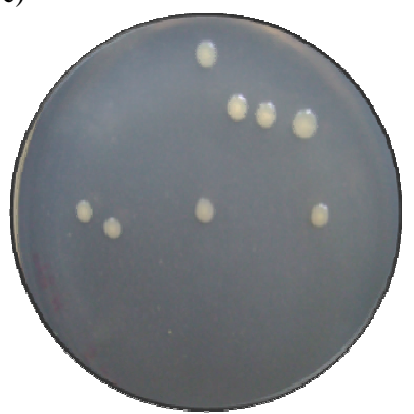

Fig. 1. Morphological changes of $P$. syringae pv. atrofaciens PDDCC 4394 strain colonies after cultivation with pyrethroid insecticides: a) alpha-cypermethrin, b) cypermethrin + chlorpyrifos, c) control without pesticide

The absence of herbicides antibacterial action enables microbial populations to exist and to change. Some authors note mutagenic effects of both the herbicidal agents [35] and extracts of plants treated with herbicides. 
Insecticides exhibit inhibitory effect on bacteria only in high concentrations, likely due to the chlorine content in the molecules of drugs. It is interesting that pyrethroid Twiks (cypermethrin and chlorpyrifos) and Alpha Super (alpha-cypermethrin) insecticides, when added to liquid culture medium for the cultivation, cause morphological dissociation of P. syringae pv. atrofaciens PDDCC 4394 colonies (Fig. 1).

Table 6

The sensitivity of wheat bacteriosis pathogens to fungicides

\begin{tabular}{|c|c|c|c|c|c|c|c|c|}
\hline \multirow[b]{2}{*}{$\begin{array}{c}\text { Active substance of fungicides, } \\
\text { concentration }\end{array}$} & \multirow[b]{2}{*}{ 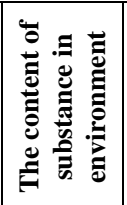 } & \multirow[b]{2}{*}{ 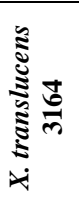 } & \multirow[b]{2}{*}{ 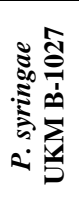 } & \multicolumn{4}{|c|}{ P. syringae pv. atrofaciens, strains: } & \multirow[b]{2}{*}{ 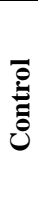 } \\
\hline & & & & $\begin{array}{l}\text { AF4, } \\
9010 \\
\text { K20 }\end{array}$ & $\begin{array}{l}\text { P203, P204, } \\
\text { 912, PDDCC } \\
\text { 4394, 9417, } \\
9404\end{array}$ & $\begin{array}{l}9747, \\
9780, \\
8462\end{array}$ & 9400 & \\
\hline \multirow{3}{*}{$\begin{array}{c}\text { I) Dithianon, } 70 \% \text {; } \\
\text { II) Metiram, } 70 \% \text {; } \\
\text { III) Mancozeb, } 64 \%+\text { Metalaxyl } \\
\text { (phenylamide), } 4 \%\end{array}$} & $\mathrm{RD} \cdot 10^{-1}$ & \multirow{3}{*}{-} & \multirow{3}{*}{-} & \multirow{3}{*}{-} & \multirow{3}{*}{-} & \multirow{3}{*}{-} & \multirow{3}{*}{-} & \multirow{3}{*}{+} \\
\hline & $\mathrm{RD}$ & & & & & & & \\
\hline & $\mathrm{RD} \cdot 10$ & & & & & & & \\
\hline \multirow{3}{*}{ I) Kresoxim-methyl, $50 \%$} & $\mathrm{RD} \cdot 10^{-1}$ & \multirow{3}{*}{+} & \multirow{3}{*}{+} & \multirow{3}{*}{+} & \multirow{3}{*}{+} & \multirow{3}{*}{+} & \multirow{3}{*}{+} & \multirow{3}{*}{+} \\
\hline & RD & & & & & & & \\
\hline & $\mathrm{RD} \cdot 10$ & & & & & & & \\
\hline \multirow{3}{*}{$\begin{array}{c}\text { I) Metconazole, } 6 \% \\
\text { II) Folpet, } 70 \%+\text { Triadimenol, } \\
1.5 \%\end{array}$} & $\mathrm{RD} \cdot 10^{-1}$ & + & \multirow{2}{*}{+} & + & + & \multirow{2}{*}{+} & - & \multirow{3}{*}{+} \\
\hline & \begin{tabular}{|l|}
$\mathrm{RD}$ \\
\end{tabular} & \pm & & \pm & \pm & & \multirow{2}{*}{-} & \\
\hline & $\mathrm{RD} \cdot 10$ & - & - & - & - & - & & \\
\hline \multirow{3}{*}{ I) Aluminium phosethyl, $80 \%$} & $\mathrm{RD} \cdot 10^{-1}$ & + & + & + & + & + & + & \multirow{3}{*}{+} \\
\hline & \begin{tabular}{|l|}
$\mathrm{RD}$ \\
\end{tabular} & \multirow{2}{*}{-} & \multirow{2}{*}{-} & \pm & \pm & \pm & \pm & \\
\hline & $\mathrm{RD} \cdot 10$ & & & - & - & - & - & \\
\hline I) Penconazole, $10 \%$; & \begin{tabular}{|c|}
$\mathrm{RD} \cdot 10^{-1}$ \\
$\mathrm{RD}$ \\
\end{tabular} & + & + & + & + & + & + & + \\
\hline & $\mathrm{RD} \cdot 10$ & \pm & \pm & \pm & & & & \\
\hline I) Tebuconazole, $16.7 \%+$ & $\mathrm{RD} \cdot 10^{-1}$ & \pm & + & + & & & + & \\
\hline Triadimenol, $4.3 \%+$ & \begin{tabular}{|l|}
$\mathrm{RD}$ \\
\end{tabular} & & \pm & & + & + & \pm & + \\
\hline Spiroxamine, $25 \%$ & $\mathrm{RD} \cdot 10$ & - & - & - & \pm & \pm & - & \\
\hline & $\mathrm{RD} \cdot 10^{-1}$ & + & & & & & + & \\
\hline 1) Tebuconazole, 12\%; & \begin{tabular}{|l|}
$\mathrm{RD}$ \\
\end{tabular} & + & + & + & + & + & \pm & + \\
\hline & $\mathrm{RD} \cdot 10$ & \pm & \pm & \pm & & \pm & + & \\
\hline & $\mathrm{RD} \cdot 10^{-1}$ & + & + & + & + & + & + & \\
\hline I) Benomyl, $50 \%$ & RD & & & & + & + & + & + \\
\hline & $\mathrm{RD} \cdot 10$ & \pm & \pm & \pm & \pm & \pm & \pm & \\
\hline
\end{tabular}

$\mathrm{RD}$ - recommended doze, these doses are presented in Table 2; - - sensitive culture, growth absence; \pm - moderately sensitive culture, weak growth; + - not sensitive culture, bacterial growth, I, II, III - different fungicides with the same effect on phytopathogens

Preparations containing mancozeb, metiram, dithianon exhibited antibacterial activity among tested preparations of fungal direction (Table 6). It is known derivatives of tio- and ditiocarbamino acids - maneb, mancozeb, thiram, zineb to inhibit different biochemical processes in cells of pathogenic fungi. Substances of this group deactivate sulfhydryl groups of enzymes, which take part in many reactions of biosynthesis and transport of substances in protoplasm. They also inactivate enzymes responsible for the ATP synthesis, the conversion of glucose into pyruvic acid, amino acids and fatty acids into acetyl coenzyme A in respiration process. Preparations based on them exhibit antibacterial activity, therefore are 
used in medical practice [36]. Maneb and mancozeb, unlike other fungicides of this chemical group, do not suppress the citrate acetate biosynthesis. The Metconazole and combined Triadimenol + Folpe preparation totally suppressed the growth of all bacteria at a dose ten-times higher than the dose recommended by producer. $P$. syringae pv. atrofaciens $\mathrm{K} 20,9400, P$. syringae UKM B-1027 ${ }^{\mathrm{T}}$ strains are selectively sensitive to ternary Tebuconazole + Triadimenol + Spiroxamine preparation in RD, but X. translucens 3164 strain are partially sensitive in concentration reduced in ten times. Fungicide at increased ten-time dose affected the growth of all experimental strains. Tebuconazole in RD only delayed growth of $X$. translucens 3164 and $P$. syringae pv. atrofaciens 9400 strains, but at a concentration ten-times higher - $P$. syringae UKM $\mathrm{B}-1027^{\mathrm{T}}$ and $P$. syringae $\mathrm{pv}$. atrofaciens AF4, K20, 9747, 9780 strains. The action of Difenoconazole triazole was similar - Table 6.

Fungicides based on triazoles are the most common and effective against fungal diseases, especially tebuconazole, whose decay products (D-5 sterols) also affect the ergosterol synthesis in fungi cells by inhibiting the demethylation at position C-14. There are mention in the literature about triazoles activity against certain bacteria (streptococci, staphylococci and bacteroides Trichomonas), but such action is poorly understood. We observed that the triazoles inhibitory effect on major crops bacterioses pathogens begins to manifest in case of contents in $100 \mathrm{~cm}^{3}$ of agar nutrient medium is greater than $0.5-1 \mathrm{~h}\left[\mathrm{~cm}^{3}\right]$. Benomyl in RD selectively reduced growth of $X$. translucens $3164, P$. syringae UKM B-1027 ${ }^{\mathrm{T}}$, P. syringae pv. atrofaciens AF4, K20 and 9010 strains, a tenfold increase of doses have affected all tested strains but did not neutralize them completely. Only increased tenfold dose of thiophanate-methyl predetermined partial growth inhibition generally sensitive to xenobiotics of $P$. syringae UKM B-1027 ${ }^{\mathrm{T}}$, X. translucens 3164 , $P$. syringae pv. atrofaciens AF4, K20, 9010. Kresoxim-methyl did not affect the growth of pathogens, even at tenfold increased concentration. Aluminium phosethyl in RD partially inhibited the growth of studied bacteria, but P. syringae UKM B-1027 ${ }^{\mathrm{T}}, X$. translucens 3164, P. syringae pv. atrofaciens 9400 strains - fully (Table 6). Perhaps impact of this substance will be more bactericidal in vivo including stimulation effect on the immune response system of the plant.

Mancozeb also shows antibacterial activity against bacteriosis pathogens of leguminous plants (Fig. 2; Tables 7 and 9).

Table 7

The influence of fungicides on the growth of legumes phytopathogenic bacteria

\begin{tabular}{|c|c|c|c|}
\hline \multirow[b]{2}{*}{ Test strains } & \multicolumn{3}{|c|}{ The diameter of zones of growth retardation [mm] } \\
\hline & Tebuconazole & $\begin{array}{c}\text { Mancozeb + } \\
\text { Propamocarb }\end{array}$ & $\begin{array}{c}\text { Mancozeb + } \\
\text { Metalaxyl }\end{array}$ \\
\hline \multicolumn{4}{|c|}{ Pseudomonas: } \\
\hline syringae UKM B-1027 ${ }^{\mathrm{T}}$ & 0 & 0 & 35 \\
\hline fluorescens 8573 & 0 & 0 & 0 \\
\hline savastanoi pv. glycinea 9176 & 0 & 0 & 25 \\
\hline \multicolumn{4}{|c|}{ Xanthomonas: } \\
\hline campestris pv. campestris UKM B-1049 & 0 & 0 & 45 \\
\hline axonopodis pv.glycines 9075 & 0 & 0 & 45 \\
\hline Pectobacterium carotovorum UKM B-1095 ${ }^{\mathrm{T}}$ & 0 & 0 & 45 \\
\hline Clavibacter michiganensis subsp. michiganensis $10_{2}$ & 0 & 20 & 27 \\
\hline Agrobacterium tumefaciens UKM B-1000 & 0 & 18 & 35 \\
\hline
\end{tabular}


Preparations containing mancozeb in combination with metalaxyl stop the growth bacteria in the studied dose recommended by the manufacturer. Growth inhibition zones of bacterial culture of $25 \mathrm{~mm}$ or more can be considered to be highly sensitive to the preparation. It is interesting the change of mancozeb with propamocarb hydrochloride action. In this combination it virtually has no effect on phytopathogenic bacteria, except C. michiganensis subsp. michiganensis $10_{2}$ and A. tumefaciens UKM B-1000 (Table 7). Perhaps propamocarb hydrochloride partially deactivates antibacterial effect of mancozeb.

The preparation has no effect on $P$. fluorescens, which is facultative phytopathogen and often found among phytoplan microbiota as saprophyte (Fig. 2; Tables 7 and 8).

a)

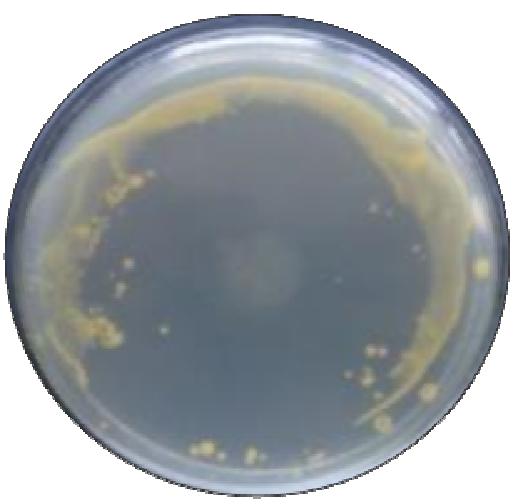

c)

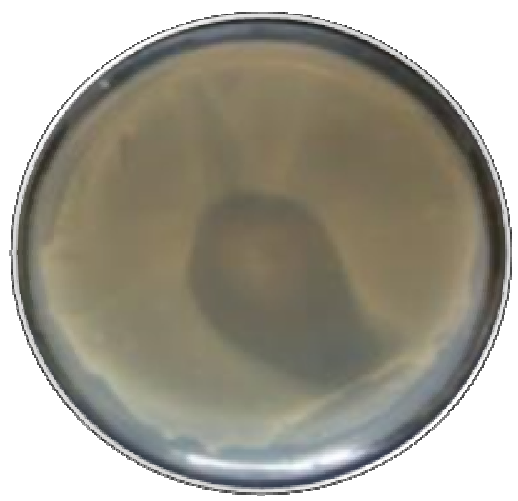

b)

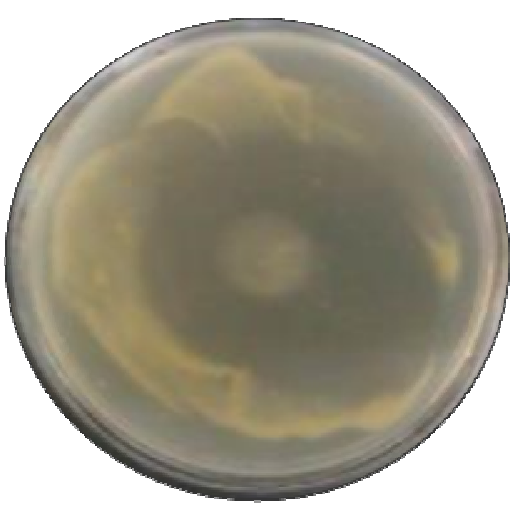

d)

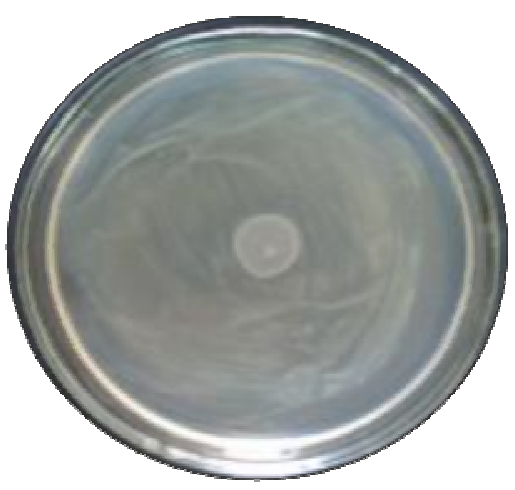

Fig. 2. Action of Mancozeb + Metalaxyl preparations on phytopathogens. Growth inhibition zones: a) C. michiganensis subsp. michiganensis $10_{2}$, b) X. campestris $8003 \mathrm{~b}$, c) A.tumefaciens UKM B-1000, d) no toxic effect on P. fluorescens

This is a positive phenomenon, because screening of plant protection products must be done by the path of least interference in the functioning of epiphytic microbiota. Antibacterial activity of tebuconazole to pathogens of angular spot $P$. savastano pv. glycinea (with few exceptions) and of wild bacterial burn of soybeans $P$. syringae 
pv. tabaci 225 is discovered. Brown spot pathogen of beans X. axonopodis pv. glycines is sensitive to Epoxiconazole with Cyproconazole (Table 8).

Effect of fungicides on soybeans bacteriosis pathogens growth

Table 8

\begin{tabular}{|c|c|c|c|c|c|}
\hline \multirow{2}{*}{$\begin{array}{c}\text { Test } \\
\text { strains }\end{array}$} & \multicolumn{5}{|c|}{ Zones of growth retardation [mm] } \\
\hline & $\begin{array}{c}\text { Epoxiconazole + } \\
\text { Cyproconazole }\end{array}$ & $\begin{array}{l}\text { Thiram + } \\
\text { Carboxyl }\end{array}$ & Tebuconazole & $\begin{array}{l}\text { Thiram + } \\
\text { Carboxyl }\end{array}$ & $\begin{array}{c}\text { Mancozeb + } \\
\text { Metalaxyl } \\
\end{array}$ \\
\hline \multicolumn{6}{|c|}{ Xanthomonas axonopodis pv. glycines: } \\
\hline 3 & 40 & 0 & 0 & 0 & 35 \\
\hline 8562 & 0 & 0 & 0 & 0 & 35 \\
\hline 8835 & 25 & 0 & 0 & 0 & 28 \\
\hline 8609 & $20-25$ & 10 & 0 & 0 & 32 \\
\hline 9075 & 20 & 15 & 0 & 0 & 40 \\
\hline 8 & 25 & 0 & 0 & 0 & 35 \\
\hline $17 \mathrm{v}$ & 35 & 0 & 0 & 0 & 35 \\
\hline $2 \mathrm{~b}$ & $20-25$ & 0 & 0 & 0 & 38 \\
\hline \multicolumn{6}{|c|}{ Pseudomonas savastanoi pv. glycinea: } \\
\hline 8541 & 0 & 0 & 15 & 0 & 30 \\
\hline 8571 & 0 & 0 & 15 & 0 & 25 \\
\hline 9072 & 0 & 0 & 15 & 0 & 25 \\
\hline 9074 & 0 & 0 & 10 & 0 & 15 \\
\hline 1 & 0 & 0 & 10 & 0 & 35 \\
\hline 4 & 0 & 0 & 20 & 0 & 28 \\
\hline $12 \mathrm{v}$ & 0 & 0 & 15 & 0 & 25 \\
\hline \multicolumn{6}{|c|}{ Pseudomonas syringae pv. tabaci: } \\
\hline 225 & 20 & 0 & 15 & 0 & 15 \\
\hline 8543 & 0 & 0 & 0 & 0 & 25 \\
\hline 8490 & 25 & 10 & 0 & 0 & 12 \\
\hline
\end{tabular}

During the analysis of bio pesticides influence on phypathogens wasn't found an effective bio preparation. Aktofit preparation with active substance which is a complex of natural avermectin of Streptomyces avermitilis is exception (Table 9).

Table 9

Effect of fungicides on grain legumes phytopathogenic bacteria growth

\begin{tabular}{|c|c|c|c|}
\hline \multirow{2}{*}{ Test strains } & \multicolumn{2}{c|}{ Zones of growth retardation [mm] } \\
\cline { 2 - 4 } & Aktofit & Fitosporin-M & Lepidotsid \\
\hline \multicolumn{3}{|c|}{ Pseudomonas: } \\
\hline syringae UKM B-1027 \\
\hline fluorescens 8573 & 0 & 0 & 0 \\
\hline savastanoi pv. glycinea 9176 & 0 & 0 & 0 \\
\hline \multicolumn{2}{|c|}{ Xanthomonas: } \\
\hline campestris pv. campestris UKM B-1049 & 0 & 0 & 0 \\
\hline axonopodis pv. glycines 9075 & 0 & 0 & 0 \\
\hline Pectobacterium carotovorum UKM B-1095 ${ }^{\mathrm{T}}$ & 25 & 0 & 0 \\
\hline Clavibacter michiganensis $10_{2}$ & 0 & 0 & 0 \\
\hline Agrobacterium tumefaciens UKM B-1000 & 0 & 0 & 0 \\
\hline
\end{tabular}

It is found that among a wide range of pathogens Aktofit preparation exhibit toxic effects only against $P$. carotovorum, which is necessary in practical and theoretical 
perspective. So «Akrofit» preparation can be recommended for fighting against parasitic microflora, ant also against the causative agent of soft rot of potatoes - P. carotovorum.

Some biological fungicidal activity are recommended as antibacteria but they effect plants just stimulating it. Broad action against fungi, bacteria and viruses "Mikosan-B" pesticide does not exhibit antibacterial properties against phytopathogenic bacteria: $P$. syringae $\mathrm{UKM} \mathrm{B}-1027^{\mathrm{T}}, \quad P$. fluorescens $8573, P$. carotovorum UKM B-1095 ${ }^{\mathrm{T}}, X$. campestris pv. campestris $8003 \mathrm{~b}$, C. michiganensis subsp. michiganensis $10_{2}$, A. tumefaciens UKM B-1000.

Researched pathogenic to leguminous crops bacteria preferably not sensitive and are resistant to chemical pesticide widely used in agriculture. Phytopathogenic bacteria of Xanthomonas genus are exeption in these studies. This genus is most sensitive to a variety of pesticides, which can be explained by the presence of adsorb properties of exopolysaccharides. Bacteria of Pseudomonas genus are the least sensitive to different preparations. However the presence of strain sensitivity, demonstrate the wide range of adaptive changes in different types of pathogens.

Despite significant economic benefits, we should not forget and underestimate the environmental impact of pesticides. Sensitive phototrophs to herbicides are the primary producers of live energy. Reducing of their amount is displayed on all levels of the food chain of the ecosystem. Also insecticides are extremely dangerous to beneficial insects, especially for bees - the main pollinators of flowering plants [37]. A work towards minimizing the impact of agrochemicals on environment should always be conducted, for example micro encapsulation for controlled isolation and prolonged action of pesticides reduces the level of their toxicity [38]. In the fight against bacteriosis of agricultural crops as an alternative to highly toxic dithiocarbamates (Thiram) the authors suggest treatment with iodine, amino acids and other stimulants of plant specific immune response of both plant and bacterial origin. Pesticides may have different impact on microorganisms, particularly phytopathogenic. Some of them, such inorganic compounds of copper, sulfur, mercury, ethylenebisthiocarbamates, exhibit rapid antibacterial activity. However, most of pesticides do not have a visible effect, which in fact does not mean the total absence of changes in the bacterial cells. Conversely, pesticides particularly poorly or bactericidal play role of limiting selection factor and their possible mutagenic effect contributes to microevolution of stable bacterial populations containing unpredictable property changes.

\section{Conclusions}

Among all tested pesticides, the thiocarbamate fungicides demonstrated significant inhibitory action on phytopathogens, but their effect may be neutralized by other constituents of multicomponent preparations. Triazole fungicides affect the causative agents of bacteriosis of crops at a dose of more than $1 \%$ of the active substance in the nutrient medium. Insecticides and herbicides have little or no effect on phytopathogenic bacteria; however they can enhance morphological dissociations of some Pseudomonas strains, thereby increasing their ability to survive. The fact that the sensitivity of phytopathogenic bacteria to pesticides is strain-dependent should be considered in practice, particularly, assessment of the antibacterial action of various preparations should not be limited to a single bacterial strain. 
Rational plant protection strategies must necessarily include accurate diagnosis of infecting agent, which will ensure optimal use of the method of protection, let use chemical preparation of directed action and reduce toxic and mutagenic burden on the environment. To improvement of ecological situation of agrocenoses biological plant protection products, which are not inferior in efficacy chemical preparations and is environmentally safe, should be implemented more widely.

\section{References}

[1] Łozowicka B, Hrynko I, Kaczyński P. Occurrence of pesticide residues in fruit from Podlasie (Poland) in 2012. J Plant Protection Res. 2015;55(2):142-150. DOI: 10.1515/jppr-2015-0018

[2] Matyjaszczyk E. Active substances used in plant protection in Poland after the European Union accession. J Plant Protection Res. 2011;51(3):217-224. DOI: 10.2478/v10045-011-0037-5.

[3] Stenersen J. Chemical Pesticides: Mode of Action and Toxicology. N.W. Corporate Blvd., Boca Raton: Florida CRC Press LLC; 2004. https://books.google.cz/books?hl=pl\&lr=\&id=WjReuSXxl4YC\&oi= fnd\&pg=PA1\&dq=Chemical+pesticides:+mode+of+action+and+toxicology\&ots=lNAfl3s3M4\&sig=B8jCF opCE56B-muyDMG-Kc7d67U\&redir_esc=y\#v=onepage\&q=Chemical\%20pesticides\%3A\%20mode $\%$ 20of\%20action\%20and\%20toxicology\&f=false.

[4] Likun G, Zhihui B, Bo J, Qing H, Huili W, Guoqiang Z, Hongxun Z. Assessing the impact of fungicide enostroburin application on bacterial community in wheat phyllosphere. J Environ Sci. 2010;22(1):134-141. DOI: 10.1016/S1001-0742(09)60084-X.

[5] Wachowska U, Stasiulewicz-Paluch AD, Głowacka K, Mikołajczyk W, Kucharska K. Response of epiphytes and endophytes isolated from winter wheat. Grain to biotechnological and fungicidal treatments. Pol J Environ Stud. 2013;22(1):267-273. http://www.pjoes.com/pdf/22.1/Pol.J.Environ.Stud.Vol.22.No.1. 267-273.pdf.

[6] Bebber DP, Holmes T, Gurr SJ. The global spread of crop pests and pathogens. J Global Ecol Biogeog. 2014;23:1398-1407. DOI: 10.1111/geb.1221.

[7] Patyka W, Gnatiuk T, Zhytkevych N, Kalinichenko A, Frączek K. Occurence of the pathogenic bacteria Pantoea agglomerans in soybean cultivation. J Progress Plant Protection /Postępy w Ochronie Roślin. 2015;55(3):280-285. DOI: 10.14199/ppp-2015-049.

[8] Trindade RS, Rodrigues R, Teixeira A, Gonsalves LS. Critical disease components of common bacteria blight to effectively evaluate resistant genotypes of snap bean. J Plant Pathol. 2012;78(3):201-206. DOI: 10.1007/s10327-012-0374-X.

[9] Rukayadi Y, Suwanto A, Tjahjono B, Harling R. Survival and epiphytic ness of a mutant of Xanthomonas campestris pv. glycines. Appl Environ Microbiol. 2000;66(3):1183-1189. DOI: 10.1128/aem.66.3.1183-1189.2000.

[10] Stockwell VO, Duffy B. Use of antibiotics in plant agriculture. Antibiotic resistance in animal and public health. Rev Sci Tech Off Int Epiz. 2012;31(1):199-210. http://ir.library.oregonstate.edu/xmlui/handle/1957/39357.

[11] Fischer SE, Jofré EC, Cordero PV, Gutiérrez Mañero FJ, Mori GB. Survival of native Pseudomonas in soil and wheat rhizosphere and antagonist activity against plant pathogenic fungi. Antonie van Leeuwenhoek, Int J General Mol Microbiol. 2010;97(3):241-251. DOI: 10.1007/s10482-009-9405-9.

[12] Imfeld G, Vuilleumier S. Measuring the effects of pesticides on bacterial communities in soil: A critical review. Eur J Soil Biol. 2012;49:22-30. DOI: 10.1016/j.ejsobi.2011.11.010.

[13] Khudhur AM, Askar KA. Effect of some pesticides on growth, nitrogen fixation and nifgenes in Azotobacter chroococcum and Azotobacter vinelandii isolated from soil. $J$ Toxicol Environ Health Sci. 2013;5(9):166-171. DOI: 10.5897/JTEHS12.029.

[14] Jastrzebska E. The effect of Chloropyriphos and Teflubenzuron on the enzymatic activities of soil. Pol J Environ Stress. 2011;20:903-910. http://www.pjoes.com/pdf/20.4/Pol.J.Environ.Stud.Vol.20.No.4. 903-910.pdf.

[15] Jacobsen CS, Hjelms $\emptyset$ MH. Agricultural soils, pesticides and microbial diversity. J Current Opinion Biotechnol. 2014;27:15-20. DOI: 10.1016/j.copbio.2013.09.003.

[16] Lew S, Lew M, Szarek J, Mieszczyński T. Effect of pesticides on soil and aquatic environmental microorganisms - a short review. PSP Fresenius Environ Bull. 2009;18(8):1390-1395. 
https://www.researchgate.net/publication/236236009_Effect_of_pesticides_on_soil_and_aquatic_environm ental_microorganisms_-_A_short_review.

[17] Boldt TS, Jacobsen CS. Different toxic effects of the sulfonylurea herbicides metsulfuron methyl, chlorsulfuron and thifensulfuron methyl on fluorescent pseudomonads isolated from an agricultural soil. Federation Eur Microbiol Soc Microbiol Lett. 1998;161:29-35. DOI: 10.1111/j.1574-6968.1998.tb12925.x.

[18] Mousumi G., Niladri P, Suprakash P, Kumar P, Murari PH, Debatosh M. Pesticides jiggling microbial transformation of phosphorus in soil. African J Microbiol Res. 2014;8(7):637-643. DOI: 10.5897/AJMR2013.6342.

[19] Kumar A, Nayak AK, Shukla AK, Panda BB, Raja R, Shahid M. et al. Microbial biomass and carbon mineralization in agricultural soils as affected by pesticide addition. Bull Environ Contam Toxic. 2012;88:538-542. DOI: 10.1007/s00128-013-1182-5.

[20] Kang JW, Khan Z, Doty SL. Biodegradation of trichloroethylene by an endophyte of Hybride poplar. J Appl Environ Microbiol. 2012;78(9):3504-3507. DOI: 10.1128/AEM.06852-11.

[21] Doty SL. Enhancing phytoremediation through the use of transgenics and endophytes. J New Phytologist. 2008;179(2):318-333. DOI: 10.1111/j.1469-8137.2008.02446.x.

[22] Taghavi S, Barac T, Greenberg B, Borremans B, Vangronsveld J, van der Lelie D. Horizontal gene transfer to endogenous endophytic bacteria from Poplar improves phytoremediation of toluene. J Appl Environ Microbiol. 2005;71:8500-8505. DOI: 10.1128/AEM.71.12.8500-8505.2005.

[23] Lakshmi KB, Madhuri T, Indrani V, Suvarnalatha DP. Effect of triazophos-an organophosphate insecticide onmicrobial population in paddy soils. Int J Cur Res Rev. 2015;7(4):64-67. http://www.scopemed.org/?mno=180863.

[24] Cycon M, Markowicz A, Borymski S, Wójcik M, Piotrowska-Seget Z. Imidacloprid induces changes in the structure, genetic diversity and catabolic activity of soil microbial communities. J Environ Manage. 2013;131:55-65. DOI: 10.1016/j.jenvman.2013.09.041.

[25] Maya K, Singh RS, Upadhyay SN, Dubey SK. Kinetic analysis reveals bacterial efficacy for biodegradation of chlorpyrifos and its hydrolyzing metabolite. J TCP Process Biochem. 2011;46:2130-2136. DOI: 10.1016/j.procbio.2011.08.012.

[26] Tago K, Okubo T, Itoh H, Kikuchi Y, Hori T, Sato Y et al. Insecticide-degrading Burkholderia symbionts of the Stinkbug naturally occupy various environments of sugarcane fields in a southeast island of Japan. J Microbes Environ. 2015;30(1):29-36. DOI: 10.1264/jsme2.ME14124.

[27] Baoguo Z, Bai Z, Hoefel D, Tang L, Wang X, Li B. et al. The impacts of cypermethrin pesticide application on the non-target microbial community of the pepper plant phyllosphere. J Sci Total Environ. 2009;407(6,1):1915-1922. DOI: 10.1016/j.scitotenv.2008.11.049.

[28] Cycon M, Zmijowska A, Wójcik M, Piotrowska-Seget Z. Biodegradation and bioremediation potential of diazinon-degrading Serratia marcescens to remove other organophosphorus pesticides from soils. J Environ Manage. 2013;117:7-16. DOI: 10.1016/j.jenvman.2012.12.031.

[29] Navarini L, Balardin RS. Foliar diseases and control by fungicides on yield and quality of wheat grains. J Summa Phytopathologica. 2012;38(4):294-299. DOI: 10.1590/S0100-54052012000400004.

[30] Feng CT, Su HJ, Chen CT, Ho WC, Tsou YR, Chern LL. Inhibitory effects of Chinese medicinal herbs on plant-pathogenic bacteria and identification of the active components from gallnuts of Chinese sumac. J Plant Dis. 2012;96:1193-1197. DOI: 10.1094/PDIS-08-11-0673-RE.

[31] Youcer-Ali M, Kacem-Chaouche N, Dehimat L, Bataiche I, Kara Ali M, Cawoy H. et al. Antifungal activity and bioactive compounds produced by Bacillus mojavensis and Bacillus subtilis. Afr J Microbiol Res. 2014;8(6):476-484. DOI: 10.5897/AJMR2013.6327.

[32] Beric T, Kojic M, Stankovic S, Topisirovic L, Degrassi G, Myers M. et al. Antimicrobial activity of Bacillus sp. natural isolates and their potentialuse in the biocontrol of phytopathogenic bacteria. J Food Technol Biotechnol. 2012;50(1):25-31. DOI: 10.1007/978-1-4614-8830-9_5.

[33] Rodríguez IF, Sayago JE, Torres S, Zampini IC, Isla MI, Ordóñez RM. Control of citrus pathogens by protein extracts from Solanum tuberosum tubers. Eur J Plant Pathol. 2015;141(3):585-595. DOI: $10.1007 / \mathrm{s} 10658-014-0566-7$.

[34] Janek T, Lukaszewicz M, Krasowska A. Antiadhesive and antimicrobial activities of the biosurfactant pseudofactin II secreted by the Arctic bacterium Pseudomonas fluorescens BD5. J BMC Microbiol. 2012;13(1):108-115. DOI: 10.1186/1471-2180-12-24.

[35] Kalyanasundaram D, Kavitha S. Effect of butachlor on the microbial population of direct sown rice. J World Acad Sci. Eng Technol. 2012;69:853-855. scholar.waset.org/1999.0/14368. 
[36] Byrne ST, Gu P, Zhou J, Denkin SM, Chong C, Sullivan D. Pyrrolidine dithiocarbamate and diethyldithiocarbamate are active against growing and nongrowing persister Mycobacterium tuberculosis. J Antimicrobial Agents Chemotherapy. 2007;51:4495-4497. DOI: 10.1128/AAC.00753-07.

[37] Whitehorn PR, Connor SO, Wackers FL, Goulson D. Neonicotinoid pesticide reduces bumble bee colony growth and queen production. J Sci. 2012;336:351-352. DOI: 10.1126/science.1215025.

[38] Litvishko VS. Reducing toxicity chemicals plant protection products. Eur Sci Rev. Vienna: "East West". 2014;5-6:112-114. https://ew-a.org/upload/iblock/3d6/ESR_5-6_2014.pdf. 